This is a self-archived version of an original article. This version may differ from the original in pagination and typographic details.

Author(s): Kaukua, Jari

Title: Avicenna on Negative Judgement

Year: 2020

Version: Accepted version (Final draft)

Copyright: @ 2020 Springer

Rights: In Copyright

Rights url: http://rightsstatements.org/page//nC/1.0/?language=en

Please cite the original version:

Kaukua, J. (2020). Avicenna on Negative Judgement. Topoi: An International Review of

Philosophy, 39(3), 657-666. https://doi.org/10.1007/s11245-016-9380-5 


\section{Avicenna on Negative Judgement}

Abstract: Avicenna's logical theory of negative judgement can be seen as a systematic development of the insights Aristotle had laid out in the De interpretatione. However, in order to grasp the full extent of his theory one must extend the examination from the logical works to the metaphysical and psychological bases of negative judgement. Avicenna himself often refrains from the explicit treatment of the connections between logic and metaphysics or psychology, or treats them in a rather oblique fashion. Time and again he is satisfied with noting that this or that question is not proper for a logician and should be dealt with in metaphysics or psychology-without bothering to refer his reader to the exact loci. The following is an attempt at a reconstruction of Avicenna's theory of negative judgement in such a broad fashion. I will begin with his analysis of negative judgement as resulting from an operation of 'removing' the predicate term from the subject term (section 1). On this basis, I will move on to discuss how he conceives of the relation between negative judgements and affirmative judgements that contain privative or metathetic terms (section 2) as well as the question of whether negative judgements can be reduced to affirmative ones (section 3). Having thus laid out his logical theory of negation, I move on to discuss the underlying metaphysics by looking at the relation between existence and non-existence, and existence and privation (section 4). Finally, I will address Avicenna's scattered psychological remarks on how we can conceive of what does not exist (section 5$){ }^{1}$

\section{Negation and removal}

The starting point of Avicenna's semantic theory is the threefold scheme laid out by Aristotle in De interpretatione 1, 16a3-9. In Avicenna's interpretation of this straightforward realist model, linguistic utterances are expressions of and refer to perceptual or intellectual mental content, and this mental content in turn is a representation of and refers to external objects or states of matter. ${ }^{2}$ The resulting theory is a causal model of reference, in which mind-

\footnotetext{
${ }^{1}$ This paper has benefitted from the perspicacious comments of Yusuf Dasdemir, Sonja Schierbaum, Mika Perälä and the anonymous referees of Topoi. My sincere thanks are due to them all.

${ }^{2}$ Shifä': al-'Ibāra I.6, 37-38 (in the following, all references by a solitary title are to Avicenna's works); cf. the very similar account in Fārābī, in De int. 24-26. To be exact, in this model linguistic expressions are further subdivided to spoken and written utterances, the latter of which are conceived as expressions of the former. For a more detailed discussion of Avicenna's semantic theory, see Inati (1984), 148-153; Black (1991), section II.2, and
} 
independent objects bring about mental content, and the mental content in turn is expressed in linguistic symbols. ${ }^{3}$ Its realism is also underpinned by the fact that it explains cultural differences in expressions and their reference by reducing them to accidental and logically unimportant features of natural languages. Extrapolating on Aristotle's brief remarks, Avicenna explicitly holds that once we abstract from the syntactic and vocabular differences between languages, the relation between mental content and its linguistic expression is quite straightforward. For instance, in his discussion of the structure of the most basic type of truthvalued utterance, the predicative statement $(q a w l)$, he notes that some languages, such as Persian, always express the copula explicitly, while others, such as Arabic, may do it only implicitly. This should not obscure the fact that in both cases the copula must be understood to be a constituent of the linguistic expression if it is to be read as an expression of the predicative judgement in the mind. ${ }^{4}$ The expressions of natural languages are, therefore, more or less clear variations on an ideal or absolute (al-mutlaq) language that is the proper object of study in logic. ${ }^{5}$ Now, because the relation between language and its mental referent is so straightforward in this model, I will take the liberty of henceforth speaking simply about positive and negative judgements, by which I mean primarily thoughts and secondarily their expressions in a natural language.

What, then, is the logical structure of judgements, and negative judgements in particular? Following Aristotle, again, Avicenna states that the minimal constituents of the most basic type of meaningful judgement, the predicative judgement, are two terms and a suitable relation or connection (ribāt) between them. In a natural language, this relation is denoted by a connecting term (lafza rābița) or the copula that ties the subject term to the predicate term. Avicenna adds that the position of the three features must be grasped as a unity without excessive effort if the judgement is to count as a genuine logical entity. ${ }^{6}$ In other words, the judgement must be such that, its inherent divisibility notwithstanding, when actually understood it must be understood as one. Having laid this groundwork, Avicenna describes the operations that yield the affirmative and negative predicative judgements as follows:

(2010), section II.A; Koutzarova (2009), 74-81; and Kaukua (2014b), 219-227. Bäck (2013) is an English translation of Shifä': al- 'Ibāra.

${ }^{3}$ Avicenna's model is complicated by the possibility of mental causation, but this is not relevant for the purposes of the present paper. For a more detailed analysis of the model, see Kaukua (2014b).

${ }^{4}$ Shifä': al-'Tbāra I.6, 37-39.

${ }^{5}$ Cf. Shifā': al-Madkhal I.4, 22; Shifā' : al- 'Ibāra I.1, 5; II.1, 79; Ishārāt I, 3; and cf. Fārābī, in De int. 27. By the time of Avicenna, the question of the universality of Aristotelian logic had been subject to fierce debate for more than a century (see Margoliouth [1905] and Black [1991]).

${ }^{6}$ Shifă ': al- 'Tbāra I.6, 38-39; cf. Ar. De int. 5, 17a9-13; and Fārābī, in De int. 54-55. 
Here it is known how terms refer, insofar as they are nothing but terms and do not signify either affirmation ( $(\bar{l} j \bar{a} b)$ or negation (salab), and that the first assertoric (al-jäzim) composition [made out] of them is a combination of two of them by way of positing ( $\bar{l} q \bar{a}$ ) one of the other or removing it (naz ihi) from the other. ${ }^{7}$

Taken in isolation, the subject and predicate terms do not assert anything, but once they are composed into a predicative judgement by the operation of positing the predicate term of the subject term or removing the prior from the latter, they constitute an affirmative or negative assertion. This, of course, is very close to Aristotle's theory of combination (synthesis) and separation (diairesis) as laid out in De interpretatione 1, 16a10-18, although the Arabic terms $\bar{\imath} q \bar{a}^{\prime}$ and $n a z^{\prime}$ do not appear in Iṣhạa ibn Hunayn's translation (d. $910 \mathrm{CE}$ ) of the De interpretatione. ${ }^{8}$

The removal of the predicate term from the subject term is the most basic operation by means of which negative judgements are produced. It is foundational to other types of negative judgements, because in the Aristotelian predicate logical framework in which Avicenna operates, the other types of judgement are all formed by connecting basic predicative judgements by means of conjunctive (muttașil, 'if ... then') or disjunctive (munfașil, 'either ... or') connectors. Although Avicenna's initial discussion of negative judgements in Shifä': alIbāra I.6 suggests that the possibility of negating composite judgements requires us to qualify the straightforward characterization of negative judgement as removal, ${ }^{9}$ the more detailed analysis of negative composite judgements in Shifä': al-Qiyās V.5 shows that an analysis of their truth conditions allows us to reduce them into combinations of the negations of their constituents.

In their simplest form, affirmative composite judgements are produced by positing two simple judgements in a conjunctive or disjunctive relation. By the same token, negative composite judgements are formed by removing the conjunctive or disjunctive relation between the constituent simple judgements. Now, this operation of removal can be exhaustively analyzed by means of positions and removals of the constituent judgements. In the case of the conjunctive judgement this is quite straightforward: its negation amounts to the negation of its

\footnotetext{
${ }^{7}$ Shifā': al- 'Ibāra I.6, 41; cf. Najāt I, 51; and Ishārāt III, 23. The definition is discussed in Hodges (2012). ${ }^{8}$ See Arisțū, al- 'Ibāra 1, 59, where Ișhāq uses tarkīb and tafṣ̂̀l for synthesis and diairesis, respectively. Al-Fārābī uses Ișhāq's terms in his uncomplicated discussion of the basic judgemental operations (see in De int. 26).

${ }^{9}$ In this context, Avicenna mentions two ways of speaking about position and removal: either as restricted to predicative judgements or as encompassing the composite judgements as well (Shifā': al- 'Ibāra I.6, 41-42). Although he does not state this explicitly, it seems plausible to understand the first way as referring to the reductive analysis and the second as reflecting the variety of logical forms encountered in basic kinds of judgement.
} 
consequent. ${ }^{10}$ When it comes to the negation of the disjunctive judgement, we must bear in mind that although Avicenna recognizes the inclusive interpretation of disjunction (' $\ldots$ or ... or both'), he holds that only the exclusive ('either ... or ... but not both') is a 'simple and true' (al-basit wa al-haqq) disjunction. ${ }^{11}$ Understood in this way, the disjunctive relation is itself a kind of removal - the 'not both' which Avicenna calls 'exclusion' ( 'in $\bar{a} d)^{12}$ —which becomes explicit in the truth-functional analysis of the negation of disjunction: it amounts to the affirmation of both constituents or the negation of both constituents. ${ }^{13}$

As an outcome of this summary analysis, we can say that Avicenna holds negative judgements to result from operations of removal. At its most basic, this removal is performed on the subject and the predicate term of a predicative judgement, that is, the predicate is removed from the subject. Avicenna also describes the operation in a way which hints towards the metaphysics underlying the logical discussion, when he says that negation is 'the judgement that something does not exist for [another] thing' (al-hukmu bi lā wujūdi shay 'in li shay'). ${ }^{14}$ Conceived in this way, negative and affirmative judgements and the operations of position and removal are complete counterparts-every affirmative sentence has a corresponding contradictory negation, and vice versa, as long as we pay careful attention to all the possible qualifications, such as categorical limitations or modal qualifications, in the judgements. ${ }^{15}$

\section{Negative and metathetic judgements}

In the initial discussion of verbs in De interpretatione 3, 16b12-16, Aristotle introduces the idea of indefinite verbs (aoriston rhèma), such as '(does) not recover' or '(does) not ail', which can be veridically said of both subjects that exist and subjects that do not exist. Later on, in $D e$ interpretatione 10, he extends this idea to cover nouns and attributes (e.g. 'not-man', 'notjust'). As a result of these ideas, we have a new class of judgements that are affirmative in form, because the connection between the subject and the predicate is a position, but negative

\footnotetext{
${ }^{10}$ Shifä': al-Qiyass V.5, 279-283. This is true in both of the cases that Avicenna distinguishes, namely in implications proper in which the constituent judgements are essentially related (fíhi ittibā un bi luzüm), and in chance connections of two unrelated judgements. Dasdemir (forthcoming) is a detailed analysis of the two types of conjunctive judgement.

${ }^{11}$ Shifă': al-Qiyās V.2, 246.

${ }^{12}$ This complication is recognized already in the introduction of the concept of removal in Shifáa': al- 'Ibāra I.6, 41-42.

${ }^{13}$ Shifā' : al-Qiyās V.5, 283-285.

${ }^{14}$ Shifā': al-'Ibāra I.6, 43; my emphasis.

${ }^{15}$ Shifă': al-'Tbāra I.6, 43-44.
} 
in content due to the indefinite predicate term. A case in point is Aristotle's example 'a man is not-just'. This gives rise to the question of how the affirmations containing indefinite termslater called by the phrase ek metatheseōs ('metathetic' or 'transposed'), ${ }^{16}$ which may have given rise to the Arabic term ma'dūl ('deflected') that Avicenna adopts ${ }^{17}$ —are related to semantically corresponding negative judgements, and as a natural consequence, how both are related to the semantically close privative terms and judgements.

Metathetic terms first surface in Avicenna's discussion of nouns as non-assertive single expressions (alfäz mufrada). In this context he states that they are expressions composed of a noun and a negative particle, but being single expressions, they entail neither affirmative nor negative judgement, despite the presence of the negative particle. ${ }^{18}$ This, I believe, is for two reasons: first, because judgements first come to be when at least two terms are combined by a copula, and a metathetic term alone is only one of the required constituents; and second, because metathetic terms can function in affirmative and negative judgements alike. That metathetic affirmations are semantically related to negations becomes clear in a later discussion devoted to metathetic and privative propositions (al-qaḍayā [...] al-ma 'dūla [...] wa al'adamīya):

It must be known that the difference between our statement ' $\mathrm{X}$ is not-Y' (kadha yüjadu ghayra kadhā) and our statement ' $\mathrm{X}$ is not Y' (kadha laysa yüjadu kadhā) is that the simple negative [proposition] is broader (a 'amm) than the metathetic affirmative [proposition] in that it is true of the non-existent insofar as it is non-existent, whereas the metathetic affirmative [proposition] is not true of that. ${ }^{19}$

The difference between the two judgements cannot be elucidated by simply noting that one is affirmative and the other negative in form, because at issue is their similarity from a pragmatic point of view, that is, the fact that they both function as negations. ${ }^{20}$ But their difference is due

\footnotetext{
${ }^{16}$ See Zimmermann (1981), lxii-lxiv. According to Ammonius, this term derives from Theophrastus, though he is somewhat uncertain about the latter's reason for introducing the term. It was either to refer to the placement of judgements in the table introduced in De interpretatione 10, 19b28-30, or to the replacement of the definite predicate by the indefinite in the same table. According to Stephanus, however, the term was designed to denote the transposition of the negative particle from the copula to the predicate.

${ }^{17}$ Ișhāa translated aoriston as ghayr muhașșal (Arisțū, al- 'Tbāra 3, 62); al-Fārābī follows him in the discussion of De int. 3 (in De int. 37-39) but introduces the term ma'dül in his comments on De int. 10 (in De int. 101-103). For a subtle analysis of al-Fārāb̄̄'s theory, see Thom (2008). Following Zimmermann (1981) and Hodges (2012), I will henceforth speak of indefinite terms and judgements containing them as metathetic terms and judgements. ${ }^{18}$ Shifä' : al-'Ibāra I.2, 12-13; cf. Ar. De int. 10, 20a31-40; for discussion, see Wolfson (1947), 180-183; Inati (1984), 154-156; and Black (1991), section II.3.

${ }^{19}$ Shifa ${ }^{\prime}$ : al- 'Ibāra II.1, 82. In all translations from this chapter, I have benefitted from Hodges (2012).

${ }^{20} \mathrm{Al}-\mathrm{Fa}$ āā $\mathrm{i}$ is explicit about this and notes further that certain features of the Arabic language, particularly the fact that the copula is normally not expressed explicitly, are prone to hide the distinction. Nevertheless, he also
} 
to their logical form, because the affirmative judgement presupposes the existence of its subject, whereas the negative judgement remains existentially neutral. ${ }^{21}$ It is because of this feature that we can make true negative judgements, but not true affirmative judgements, of things that do not exist. To use Avicenna's own example, the negative 'the phoenix does not see' (al- 'anqā' laysa huwa bașìran) is a true statement whereas the affirmative metathetic 'the

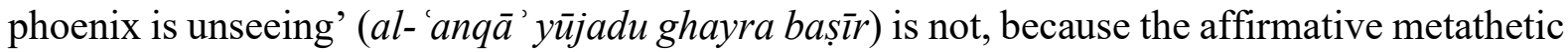
is committed to the existence of the phoenix - as highlighted by the choice of yujjadu in the position of the copula. ${ }^{22}$

As regards privative affirmations, Avicenna conceives of them as a restricted type of metathetic affirmations:

The affirmative privative [proposition] falls in the domain of the metathetic affirmative and the simple negative [proposition], and the status of the two privative [propositions in relation to] the two metathetic [propositions] is that the affirmative resembles the affirmative metathetic [proposition] and the negative resembles the negative metathetic [proposition]. The affirmative metathetic [proposition] is true of [what] the affirmative privative [proposition is true of], but not conversely, because the affirmative metathetic is broader than the affirmative privative [proposition]. ${ }^{23}$

To spell out the difference by means of modifications of Avicenna's examples, we can say that the metathetic affirmation 'Zayd is unjust' is broader than the privative affirmation 'Zayd is oppressive', because Zayd's being unjust can be due to a number of specific attributes other than 'oppressive'. For instance, his decisions may be biased in favour of his friends and relatives, but this alone would not warrant the judgement that he is oppressive towards others. It is in this sense that the privative affirmation is more specific than the metathetic affirmation.

Supposing that this brief review has shown that negative, metathetic and privative judgements have considerable semantic overlap, ${ }^{24}$ it has not yet done much to elucidate the logical and epistemic relations between them. In particular, we are unclear of whether the metathetic and privative judgements are based on operations that are distinct from, perhaps

holds that the two propositions should be logically distinguished and makes the distinction along the same lines as Avicenna. (in De int. 101-103.)

${ }^{21}$ Cf. Ishārāt III, 27-28. Fārābì, in De int. 101, introduces the idea that the metathetic affirmation entails the positive existence of its subject as his own departure from some of the commentators. For a slightly different reconstruction of the difference between the metathetic affirmative and the negative judgement, see Hodges (2012).

${ }^{22}$ Shifā' : al- 'Ibāra II.1, 82.

${ }^{23}$ Shifä' : al-'Ibāra II.1, 83.

${ }^{24}$ For a useful analysis of this overlap, as well as an assessment of the Arabic discussion in the broader historical framework, see Wolfson (1947). 
even independent of, the removal that produces the negative judgement. Avicenna introduces this question as his main focus in chapter II.5 of Shifā' : al- 'Ibāra.

Avicenna's focus here is on whether the opposition (taqābul) between an affirmative judgement and its negation is stronger than that between two affirmative judgements which have the same subject but contrary predicate terms. Avicenna starts his investigation by making an important distinction between opposition in the extramental 'nature of things' ( $f \grave{\imath}$ tabi 'ati al$u m \bar{u} r$ ) and opposition in belief, or 'assent and judgement' (min haythu al-tașdīqu wa al-hukm). He states bluntly and with little elucidation that as far as the things themselves are considered, the opposition between contrary attributes is stronger. The reluctance to engage with details here has a systematic basis, for the question concerns the primacy of existence and positive attributes in relation to non-existence and privative attributes; hence, it is a metaphysical question and should not be engaged with in a logical treatise. I will deal with this question in the next section, but let us now focus on opposition in belief, which Avicenna recognizes as a topic proper for a logician. ${ }^{25}$

In the case of belief the situation is contrary to the things themselves: it is the opposition between affirmation and its negation that is stronger. This is because our conception of the contrariety of two judgements with the same subject but contrary predicate terms depends on a more basic conception of the contradiction between the relevant affirmation and negation.

Let us consider some one subject, of which it is true that it is good, when it is believed to be evil and [when] it is believed not to be good (u'taqida fihi annahu laysa bi khayr) — which of the two beliefs is more strongly opposed [to the truth] in itself? If it were not the case that evil is not good, then the belief that it is good and that it is evil would not be impossible, and if evil were replaced with something that is neither good nor evil, then nevertheless the belief that it is good and that it is not good would be impossible, for many of [the things] that are not good are not evil. Hence it is shown that the opposition in the first belief is not due to the two beliefs being contraries (mutadāaddayn) but due to the two judgements being contradictory (mutanāfiyayn), and the primary contradiction is only that which is between affirmation and negation. ${ }^{26}$

Avicenna's point here is that it is not possible to conceive of two attributes as contraries unless one has already implicitly conceived that one attribute entails the negation of the other. The conceived contrariety between good and evil is not due to any positive feature of evilnessbeing pure privation, it has none-but only due to its being (implicitly or explicitly) conceived

\footnotetext{
${ }^{25}$ Shifă' : al- 'Ibāra II.5, 124. The concern over the transgression of the limit between logic and metaphysics is frequent in both al-Fārābī and Avicenna.

${ }^{26}$ Shifá' : al- 'Ibāra II.5, 125; my emphasis.
} 
as not being good. From a logical point of view, the falsity of false predications is reducible to the evident falsity of negating a term of itself. The semantic opposition between good and evil notwithstanding, the false statement 'good is evil' is not logically impossible unless we veridically hold that evil is not good and thereby understand that the statement entails the logically impossible 'good is not good'. ${ }^{27}$

Another argument slightly later in the same chapter corroborates the point: we can form a contradictory negative judgement for any affirmative judgement, but it is not the case that all predicable attributes have contrary attributes as their counterparts. A case in point is fourness, for we can always juxtapose a statement of the form 'the number of $\mathrm{X}$ is four' with 'the number of $\mathrm{X}$ is not four', but not with another affirmative statement that has a contrary attribute. The particular case of attributes like fourness betrays the more general fact that holds even in cases of terms that do have contraries: it is a necessary condition of the contrariety of the two affirmations that the contrary terms are understood to mutually entail the negation of each other. By the same token, although all terms have contradictory metathetic terms, not all metathetic terms correspond to equivalent positive terms. For instance, although we can say that 'the number of $\mathrm{X}$ is not-four', there is no meaningful positive term by which 'not-four' could be replaced salva veritate. Again, this is not peculiar to fourness; rather, it is universally true that the opposition between an affirmative judgement and its contradictory negative is primary and foundational to the opposition between the affirmative judgement and another, contrary affirmation. ${ }^{28}$

Avicenna sums up the relation between the contradictory negation and the affirmation of a contrary succinctly when he speculates on Aristotle's reasons for including their treatment in a logical treatise devoted to the structure of linguistic statements and corresponding beliefs:

The purpose [of these remarks] is, first, to indicate that contrariety in things does not as such necessitate contrariety in beliefs, rather things must be contradictory before they can be contrary in beliefs. Second, [their purpose is] to indicate that the beliefs are not [thereby] contradictory and that beliefs are not [thereby] combined [so that] their contrariety is shown. ${ }^{29}$

Despite its density, the passage makes a clear point. It states that contrariety in mindindependent reality has no necessary bearing on our beliefs concerning those things. Although there are mind-independent contrary things and attributes, such as the colours black and white,

\footnotetext{
${ }^{27}$ Shifā ': al- 'Ibāra II.5, 125-126; cf. Ar. De int. 14, 23b21-32.

${ }^{28}$ Shifā' : al- 'Ibāra II.5, 129; cf. Fārābī, in De int. 209-210.

${ }^{29}$ Shifā' : al- 'Ibāra II.5, 126; cf. 127.
} 
we can perfectly well refrain from thinking about their contrariety. In order to conceive of them as contraries, we must first combine the black and the white in one thought or statement which makes the contrariety evident. But when it comes to thoughts and statements, contrariety is dependent on the logically prior relation of contradiction: in order to be understood as the contrary of 'black', 'white' must be understood to entail the denial of black. In this sense, contradiction, and thereby the negation through which the contradiction is formed, is logically prior to contrariety and thereby to metathetic and privative terms.

\section{The question of priority between affirmative and negative judgements}

Supposing we have shown that Avicenna took metathetic and privative affirmations to depend on negation, we are still unclear of what he thought about the more basic relation of affirmation and negation pure and simple. The question is: are position and removal equally foundational logical operations, or is one reducible to or based upon the other? Avicenna describes the relation between affirmation and negation in terms of essence and its concomitants:

We say that when we say of the good that it is good, we speak the truth, and when we say of it that it is not evil, we speak the truth. However, our truth about it when we say that it is good is complete truth about its essence, whereas our truth about it when we say that it is not evil is truth about it concerning something that is not its essence. The good is good due to its essence, but as for its not being evil, [this] occurs to it accidentally when it is opposed to something which is other than its essence and incompatible with its essence, that is, evil, so that that thing is negated of it. The assertion (ithbāt) of good is completed for it due to its essence, whereas negation is completed for it due to another, and you know already that negations are concomitants akin to these things, not one of the [things] entailed by the essence. ${ }^{30}$

We can affirm an essence and its necessary constituents of the essence itself without considering anything apart from it. This is not true of negation, however, for although it may seem that an essence (the essence of good, say) entails a number of negative judgements (such as 'good is not evil'), none of these are entailed by the essence as such. On the contrary, the negative judgement requires relating the essence to what is other than it — that which it is held not to be. Slightly later on, Avicenna states that knowing all the negations entailed by an essence is not necessary for knowing the essence. ${ }^{31}$ We can know what something is and still

\footnotetext{
${ }^{30}$ Shifā' : al- 'Ibāra II.5, 127; cf. Ar. De int. 14, 23b15-20.

${ }^{31}$ Shifā' ' al- 'Ibāra II.5, 128.
} 
be unaware of many of the things it is not. This is because the truth of the negative statements may be entailed by the essence of the thing denoted by the subject term, or the thing considered in itself, but they can be conceived only by explicitly relating the thing to what is removed from it.

In this sense, it seems that any negative judgement of an essence is founded upon an (implicit) affirmative judgement about that essence. Whenever I think about an essence (say, humanity), my thought has as an implicit propositional structure-I think about the essence in terms of what it is by thinking of the constituents of its māhiyya or quiddity (rationality and animality in the case of humanity) - and the content of this implicit proposition is the reason for negating a given predicate ('stone', say) of the subject. But nothing suggests that Avicenna takes the logical operation of removal to be reducible to the operation of position; a negative judgement can be completed only when both the subject and the predicate are understood in this manner, but the removal of the predicate from the subject is an operation of its own. Now, it may seem that Avicenna thereby subscribes to the sort of 'dissolution' (Auflösung) theory of negation that Frege ridiculed in his 1918 treatise on negation. I believe that an examination of Avicenna's theory of negative judgement against one facet of Frege's critique will prove illustrative here.

According to Frege, the dissolution model is wrong because the idea of dissolving, or to use the Avicennian term, removing the predicate from the subject goes against the evident fact that negative judgements are unitary wholes-every bit as much as the corresponding affirmative judgements. ${ }^{32}$ When you think the thought 'Zayd is not a table', you do not dissolve or erase tableness from Zayd or Zayd from tableness - rather, you think of the two together in a specific way. ${ }^{33}$

Now, it is true that 'removal', Avicenna's term of choice for the operation that results in a negative judgement, suggests that he subscribes to what Frege calls the dissolution model. But as we saw in the first section, Avicenna holds that truth-valued judgements are first yielded when two terms are connected by a connector into a judgemental unity; none of the constitutive parts of the judgement have a truth value when considered in isolation. It also became clear

\footnotetext{
${ }^{32}$ Frege (1918-1919), 147-148.

${ }^{33}$ This argument from the unity of judgement or thought is not the only one Frege introduces. He also argues that the dissolution model fails to account for double negation and that a model that treats affirmation and negation as two kinds of assertion is more economical and hence preferable (Frege [1918-1919], 148-149, 154). I believe that Avicenna's model can be developed to deal with double negation, since his account of the truth conditions of affirmation and negation is quite straightforward: a negation is true iff the corresponding affirmation is false, and by the same token, a double negation is true iff the corresponding single negation is false. But since such an extrapolation is rather far removed from what Avicenna explicitly considers, I refrain from further analysis here. By the same token, the question of the explanatory economy of the two theories cannot be addressed here.
} 
that Avicenna understands position and removal to be two distinct types of judgementproducing connection. Despite its name, removal is therefore a way of relating a predicate term to a subject term - that is, a way of producing a new judgemental unity, not the dissolution of a pre-existing unity. ${ }^{34}$

Avicenna's decision to stick with the Aristotelian term 'removal' makes sense if we consider the dependence of negation on the positive givenness of the subject and the predicate term, as well as the entailed implicit affirmations concerning the constituents of their quiddities. This, however, is not incompatible with conceiving of the act of removal as an independent way of relating the two terms and thereby producing a new kind of judgemental unity - in Fregean terms, a single thought that contains the subject and the predicate in a structural unity established by the negative connector.

\section{Non-existence and privation}

We have learned that Avicenna took affirmative and negative judgements to be based on two distinct and mutually irreducible operations. At the same time, the act of removal presupposes the initial positive givenness of the two terms that it connects into a negative judgement. This requirement is ultimately based on the metaphysical relation between existence and nonexistence, a relation to which Avicenna already hinted in his alternative definition of negation as 'the judgement that something does not exist for [another] thing' ${ }^{35}$

Avicenna addresses the question of the relation of existence and non-existence in a discussion of the primary, or transcendental, concepts 'thing' (shay') and 'existent' (mawjūd). According to him these concepts are transcendental in the medieval Latin sense of the word, that is, because they are true of all existing things. Hence, they are extensionally identical, but since it clearly makes sense to speak of things that do not exist, it seems that the two terms are different in meaning, or intensionally distinct. ${ }^{36}$ The question then is whether one of them is metaphysically primary, and if so, which one.

Avicenna inherited this question from the dialectical theologians who had been debating questions related to the notion of thing since at least the ninth century CE. Two broad questions

\footnotetext{
34 There is a peculiar feature of the Arabic which may have contributed to this conclusion, for the negative copula laysa is syntactically independent of its positive counterparts - and every bit as productive of judgemental unity. ${ }^{35}$ Shifä' ': al- 'Ibāra I.6, 43; see section I above.

${ }^{36}$ For a discussion of these notions in terms of the mediaeval transcendentals, see Koutzarova (2009), 339-350.
} 
arising out of the Qur'ān are particularly relevant here: whether God is a thing and whether God's knowledge of things before their creation implies that the notion of thing is extensionally broader than the notion of existent. In their answer to the last question most Mu tazilite theologians came to hold that the Qur'ānic shay' should indeed be interpreted as encompassing both existing and non-existing things. Since 'thing' includes both existing things and the divine and human Meinongian objects which 'existent' leaves out, it is the broader in scope of the two. In Avicenna's reconstruction of the terms of debate, this means that the Mu'tazilites conceive 'existent' as a species of 'thing' and thus posterior to it as far as the metaphysical order of transcendental notions is concerned. ${ }^{37}$ This is of immediate relevance to our topic, for if 'thing' were the most general concept, then our thoughts and judgements concerning nonexisting things would be independent of existence altogether, and by the same token, our negative judgements would be independent of the prior positive givenness of its terms.

And indeed, it is in his defence of the primacy of 'existent' over 'thing' that Avicenna denies the coherence of the idea of absolute non-existence entailed by the Mu 'tazilite shay' and argues for the dependence of conceived non-existence on a certain type of existence.

When it is said that a thing is that about which information is given, it is true. But what is then said with this, [namely] that a thing may be absolutely non-existing (qad yakūna ma 'dūman 'alā al-ițlāq), is a matter that must be looked into. If by 'non-existing' is meant that which does not exist in concrete (al-ma 'dūma fì al-a yān), it can be like that, and it is possible that a thing is established in the mind [but] does not exist among external things. But if [something] other than that is meant, it is false. There would be no information whatsoever about it, nor would it be known, unless it is conceived in the soul. As regards [the idea] that it is conceived in the soul as a form that refers to an external thing, by no means. ${ }^{38}$

Avicenna grants the Mu 'tazilites that 'thing' is a transcendental notion: whenever we speak, or give information, we are forced to speak about some thing. But he rejects their further claim that 'thing' is broader than 'existent' as based on a faulty grasp of the different types of existence. It is true that we can think of and speak about things that do not exist in reality. But when we do this, the things that do not exist must be somehow there in the mind-which is a kind of existence. It is of no use to say that the non-existing things are represented by forms, for the object of thought is the form — or to press the point, exists as a form-which is argued not to exist. Things in the mind are not genuinely Meinongian, or absolutely non-existing.

\footnotetext{
${ }^{37}$ For a more thorough discussion of Avicenna's approach against its theological background, see Jolivet (1984) and Wisnovsky (2003), 145-160.

${ }^{38}$ Shifä': al-Ilāhìyāt I.5.12, 25; my emphasis.
} 
The immediately following paragraph makes an explicit connection to the question of affirmative and negative judgements:

As regards the information, that is because information is always about something realized in the mind ('an shay'in mutahaqqiqan fi al-dhihn). No information is given about the absolutely non-existing by way of affirmation, and even when information about it is given by way of negation, existence has been given to it in some respect in the mind. That is because our saying 'it' entails (yutadammanu) a reference, and reference to what does not exist - that which has no form in any respect at all in the mind-is impossible. How can anything be affirmed about what does not exist, when the meaning of our saying that the non-existing is such and such is that the attribute 'such and such' occurs to the non-existing, there being no difference between what occurs and what exists? ${ }^{39}$

The point is clear: even when a thing is simply said not to exist, let alone when a predicate is removed of a subject that is conceived to exist, both the subject and the predicate must exist in the mind. Avicenna's argument here can be spelled out by means of his semantic theory. If the utterances that refer to non-existing things are to be meaningful, they must refer to something in the mind, and what is there in the mind exists in the mind. If this reference is lacking, the utterances are not expressions in the first place but mere acoustic phenomena or stains on a leaf of paper. As Avicenna goes on to state, the enigmatic phenomenon of non-existence first emerges at the level of mental existence and its reference to the extramental reality:

We say that we have knowledge of what does not exist, because when the meaning occurs only in the soul and there is no reference to [what is] external in it, then what is known is just what is in the soul. The assent posited (al-tașdīq al-wāqi ) between what is conceived of its two parts, is that the nature of this known [thing] allows that an understood relation to what is external occurs for it, although it has no [such] relation at the present time. Nothing else is known. ${ }^{40}$

Avicenna states clearly, if rather densely, that our thoughts and judgements about non-existing things and attributes are possible due to an intentional relation between the content in the mind and the external world. This intentional relation is brought about through the epistemic act of assenting $(\operatorname{tas} d \bar{l} q)$ to what is conceived (tașawwur). ${ }^{41}$ Negative judgements that involve non-

\footnotetext{
${ }^{39}$ Shifä': al-Ilāhìyāt I.5.13, 25.

${ }^{40}$ Shifä': al-Ilāhìyāt I.5.16, 26.

${ }^{41}$ For a reconstruction of an Avicennian theory of intentionality along these lines, see Kaukua (2014b). In brief, the idea is that while acts of tașawwur produce mental content, the intentional relation between that content and the external world is first produced through an act of tas di $q$. It is important to note that there are different kinds of tașdiq; in some cases we give our assent after careful conscious consideration (for instance, when deciding
} 
existence are not different from affirmative judgements in this general regard; the difference is that in the case of negative judgements one recognizes that the intentional relation fails to hold, there being nothing corresponding to the posited mental content in the external world. It is important to note that this recognition of non-existence depends on the prior existence of the mental content, for we can only deny what is somehow present to us, or as Avicenna puts it, 'existence is known through itself (yu'arifu bi dhätihi) [but] non-existence is in one respect known through existence'. ${ }^{42}$ There is no absolute non-existence, and the recognition of nonexistence that takes place in a negative judgement depends on something existing in the mind.

But what about privation, is it not a sort of non-existence in mind-independent reality? ${ }^{43}$ According to Avicenna, privation can be approached from the two points of view of mental and extramental existence. As we have already seen him claim in Shifā' : al- 'Ibāra II.5, in mental existence the contrariety of privation and the prevalence or possession (malaka) of an essence is reducible to the contradiction between an affirmative and a negative judgement. ${ }^{44}$ Although evil really is contrary to the good regardless of whether we know this or not, we can only think about their contrariety once we have realized that evil is not good (or vice versa). In the extramental reality of concrete things, on the other hand, the contrariety of privation and prevalence is the basis for all other forms of opposition. A stable body is not moving only because it has the privative property of being at rest - not because of any purely negative property such as non-movement, for there is no negative existence in extramental reality. ${ }^{45}$ From a metaphysical point of view, privation thus has a certain reality that absolute nonexistence lacks; indeed, it serves a crucial purpose in the explanation of all physical processes, for together with the subject that changes and the form that is actual in the beginning of the change, it is one of the three principles required in it. As Avicenna puts it, "if there were no privation [...], it would be impossible for anything to change or be perfected, and the [present] perfection or form would have occurred for eternity'. ${ }^{46}$ At the same time, privation is a type of

\footnotetext{
whether or not to believe another person's report) whereas in other cases, such as perception, we do this almost automatically. From the point of view of the production of the intentional relation, however, the cases are similar. ${ }^{42}$ Shifä ': al-Ilāhìy $\bar{a} t$ I.5.24, 28; cf. I.5.18, 26-27; VII.1.9, 238; as well as the remarks on thoughts about the past and the future in III.10.22-23, 122-123.

${ }^{43}$ One must be cautious when distinguishing between non-existence and privation in Avicennian texts, because the two are normally glossed over by a single term, 'adam. While one could perhaps press the case of translating all instances as 'non-existence', this would obscure the natural connection in many contexts to Aristotelian discussions of sterēsis. I have therefore decided to use both 'non-existence' and 'privation' as translations of the Arabic term, each choice depending on the context.

${ }^{44}$ See Shifä al- 'Tbāra II.5, 124; and section 2 above. Cf. Shifáa': al-Ilāhìyāt VII.1.5, 237-238.

${ }^{45}$ Privation is also said to provide the reference for our negative judgements; see Shifä': al-Ilāhìyat III.6.10, 98 ('facing the affirmative [utterance] is permanence (al-thubüt), and facing the negative [utterance] is privation'); VII.1.5, 238; and VII.1.9, 238.

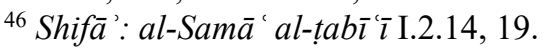


non-existence $(l \bar{a} w u j \bar{u} d)$, albeit not absolute non-existence but the non-existence of the form of which it is the privation. ${ }^{47}$

As the non-existence of the form of which it is the privation, privation is still dependent on existence. It cannot be understood or defined by itself but only in relation to that form. ${ }^{48}$ This dependence is either absolute, as in the case of pure privations like evil or sickness, or relative to an attribute's being considered from the point of view of contrariety. An example of the latter is red, which can be legitimately conceived as the privative contrary of blue, but not without an important qualification: the red is not not-blue pure and simple but a combination of not-blue and actual redness. ${ }^{49}$

Hence, despite a certain mind-independent reality that Avicenna accords to privations, existence is metaphysically prior to non-existence also in their case. Moreover, in order to be grasped as a privation, the extramental state of affairs must be related to something existing in the mind that is then recognized not to exist in reality.

\section{Conceiving the non-existent: the psychological background}

In the Avicennian universe, the human intellect is uniquely situated between pure intelligibles and physical things. For this reason it is capable of thinking of objects that are inaccessible to the eternally actual separate intellects—-such as privations:

As for privations, the intellect does not conceive them when it is in act absolutely, because privation is apprehended insofar as possession is not apprehended. Hence, what is apprehended of privation insofar as it is privation and evil insofar as it is evil is something that is potential and lacks perfection. If an intellect apprehends it, it only apprehends it because it is related to it through potency (bi al-iḍaffati ilayhi bi al-quwwa). So the intellects to which nothing potential is mixed do not understand privation or evil insofar as they are privation and evil, nor do they conceive them. There is nothing in existence that is evil absolutely. ${ }^{50}$

\footnotetext{
${ }^{47}$ Shifā' $:$ al-Samā'al-tabì ‘̀ I.3.10, 32.

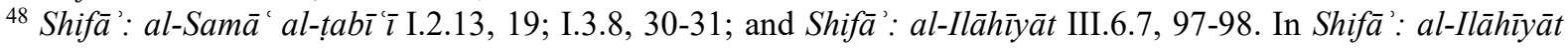
VII.1.6-8, 238, Avicenna lists six different ways in which we can speak of privation, dependence on the corresponding positive attribute being common to them all.

${ }^{49}$ Cp. Shifä' : al-Ilāhìyāt VII.1.10-11, 239 and IX.6.3, 340 with VII.1.9, 238. The two cases are also different in that the opposition of a privation and the corresponding form has no mean, whereas the opposition of two positive contraries has a mean and allows a gradual transformation from one contrary to the other (VII.1.20, 242).

${ }^{50}$ Shifä' : al-Nafs V.5, 238.
} 
Privations, and non-existence in general, are only grasped by intellects that are not fully actual. In other words, thinking about them is the sole prerogative of the human intellect, which is poised between the potency derived from its connection to matter and the immaterial actuality of second perfection proper to its nature as an intellect. We are capable of thinking about privations because we are potentially related to them, whereas a fully actual intellect will only think about the forms of which the privations are privations.

This idea seems to be an extrapolation of Aristotle's brief remarks about our understanding of evil and black in De anima III.6, 430b22-23. Avicenna is almost as evasive as the Stagirite about what it means to be 'related to [a privation] through potency', but it seems natural to assume that this potency must be based on the material intellect and so due to the human intellectual soul's relation to the body. ${ }^{51}$ According to Avicenna, the material intellect should be conceived as a subject for the intelligible forms that come to be in the soul through the co-operation of the faculties of the sensible soul and the emanation from the active intellect. ${ }^{52}$ Moreover, it is a subject in which the intelligible forms appear in succession; for as long as it remains connected to the body, the human intellect cannot grasp all intelligible forms simultaneously, and so it always retains a potency for grasping what it does not presently grasp. ${ }^{53}$ Because of this potentiality in us, we can entertain different kinds of mental content and compare forms with each other ${ }^{54}$ in all kinds of ways that are not available to the eternally actual celestial intellects, which are confined to the eternal contemplation of their positive but immutable content. Some of these comparisons reveal discrepancies between the compared forms which we then conceive as instances of privation or non-existence. This can be either between a perception caused by the external world and a form entertained in the mind, or between two forms entertained in the mind without any immediate extramental causal input. In any case, the apprehension of a privation requires the mental existence of at least two posited forms. 55

Having said that, one must admit that it is difficult to find a straightforward account of our apprehension of non-existence in Avicenna-indeed, there seems to be something primitive about it. However, the requirement of comparable positive content allows us to infer that the apprehension of non-existence hinges on our capacity to produce mental content that is not immediately caused by extramental things, that is, on the internal senses. I cannot go into

\footnotetext{
${ }^{51}$ Shifä ' : al-Nafs I.5, 48-50.

${ }^{52}$ Shifä' : al-Nafs V.6, 239-241.

${ }^{53}$ Shifä': al-Nafs V.2, 220-221; V.6, 241, 247-248.

${ }^{54}$ Shifä': al-Nafs V.3, 222.

${ }^{55} \mathrm{Cf}$. the remarks on the perception of pain in Shifä ': al-Ilāhīyāt IX.6.2, 340.
} 
the details of the relatively complex co-operation of these faculties here, ${ }^{56}$ suffice it to point out that the full psychological explanation of negative judgement would involve the entire cognitive apparatus of the human soul, because the human intellect cannot produce any content on its own, ${ }^{57}$ let alone such that has no reality without the mind.

\section{Conclusion}

As we have seen, Avicenna's theory of negative judgement is a systematic development of the ideas Aristotle had laid out in the De interpretatione. He conceives of negation as due to a mental act of removing the predicate term of a judgment from its subject term. As the result of such a removal, the negative judgement presupposes the prior positive givenness of the two terms, and this relation of priority has a parallel in Avicenna's metaphysical analysis of the relation between existence and non-existence or existence and privation. Finally, it is interesting to note that Avicenna locates the capacity of negative judgement in the human potential intellect, thereby suggesting (albeit rather elliptically) that it is an exclusively human possibility.

\section{Bibliography}

Badaw̄̄ 'AR (ed) (1948) Manțiq Arisțū. Mațba a Dār al-Kutub al-Mișrīya, Cairo (pp. 57-99 = Arisțū, al-'Ibāra)

Black DL (1991) Aristotle's Peri hermeneias in Medieval Latin and Arabic Philosophy: Logic and the Linguistic Arts. Canadian Journal of Philosophy 21:25-83

Black DL (1993) Estimation (Wahm) in Avicenna: The Logical and Psychological Dimensions. Dialogue 32:219-258

Black DL (2000) Imagination and Estimation: Arabic Paradigms and Western Transformations. Topoi 19:59-75

Black DL (2010). Intentionality in Medieval Arabic Philosophy. Quaestio 10:65-81

\footnotetext{
${ }^{56}$ For extended analyses, see Black (1993, 2000) and Kaukua (2014a).

${ }^{57}$ Avicenna subscribes firmly to the Aristotelian idea that in this life thinking always requires a phantasm (see Ar. De an. III.7, 431a15-17); see, for instance, his refutation of an intellectual memory in Shifä' : al-Nafs V.6, 244248.
} 
Bäck A (2013) Avicenna / Ibn Sīnā. Al-'Ibāra. Avicenna's Commentary on Aristotle’s De interpretatione Part One and Part Two. Philosophia Verlag, Munich

Dasdemir Y (forthcoming) Avicenna on the Opposition of Conditional Propositions. Unpublished article manuscript.

El-Khodeiri M (ed) (1970) Ibn Sina. Al-Shifa. La logique III De l'interpretation (al-ibara). Dar el-katib al-'arabi, Cairo (= Shifä' ': al-'Ibāra)

Fakhrī M (ed) (1985). Al-Ḥusayn Abū 'Alī ibn Sīnā. Kitāb al-Najāt. Manshūrāt Dār al-Āfāq al-Jadīda, Beirut (= Najāt)

Forget J (ed) (1892) Ibn Sīnā. Le Livre des théorèmes et des avertissements publié d'après les mss. de Berlin, de Leyde et d'Oxford. E. J. Brill, Leiden (=Ishārāt)

Frege G (1918-1919) Die Verneinung. Beiträge zur Philosophie des deutschen Idealismus $1: 143-157$

Hodges W (2012) Affirmative and Negative in Ibn Sīnā. In Dutilh Novaes C \& Hjortland OT (eds) Insolubles and Consequences: Essays in Honour of Stephen Read. College Publications, London

Inati S (1984) Ibn Sina on Single Expressions. In: Marmura ME (ed) Islamic Theology and Philosophy: Studies in Honor of George F. Hourani. State University of New York Press, Albany

Jolivet J (1984) Aux origines de l'ontologie d'Ibn Sīnā. In: Jolivet J \& Rashed R (eds) Études sur Avicenne. Les Belles Lettres, Paris

Kaukua J (2014a) Avicenna on the Soul's Activity in Perception. In: Silva JF \& Yrjönsuuri M (eds) Active Perception in the History of Philosophy: From Plato to Modern Philosophy. Springer, Cham et al.

Kaukua J (2014b) The Problem of Intentionality in Avicenna. Documenti e studi sulla tradizione filosofica medievale 25:215-242

Koutzarova T (2009) Das Transzendentale bei Ibn Sīnā. Zur Metaphysik als Wissenschaft erster Begriffs- und Urteilsprinzipien. Brill, Leiden \& Boston

Kutsch W \& Marrow S (eds) (1960) Alfarabi's Commentary on Aristotle's Peri hermēneias (De interpretatione). Imprimerie Catholique, Beirut (= Fārābī, in De int.)

Madkour I et al. (ed) (1952) Ibn Sīnā. Al-Shifā'. La logique I - L'Isagoge (al-madkhal). Imprimerie Nationale, Cairo (=Shifā' : al-Madkhal)

Margoliouth DS (1905) The Discussion between Abu Bishr Matta and Abu Sa id al-Sirafi on the Merits of Logic and Grammar. Journal of the Royal Asiatic Society 37:79-129 
Marmura ME (2005) Avicenna. The Metaphysics of The Healing. A Parallel English-Arabic Text Translated, Introduced, and Annotated. Brigham Young University Press, Provo (= Shifä': al-Ilāhīyāt)

McGinnis J (2009) Avicenna. The Physics of The Healing. A Parallel English-Arabic Text Translated, Introduced, and Annotated. 2 vols. Brigham Young University Press, Provo

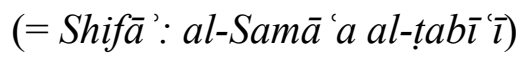

Rahman F (ed) (1959) Avicenna's De Anima (Arabic Text). Being the Psychological Part of Kitāb al-Shifā'. Oxford University Press, London (=Shifā' $:$ al-Nafs)

Wisnovsky R (2003) Avicenna's Metaphysics in Context. Cornell University Press, Ithaca

Wolfson HA (1947) Infinite and Privative Judgements in Aristotle, Averroes, and Kant. Philosophy and Phenomenological Research 8:173-187

Zayed S (ed) (1964) Ibn Sīnā. Al-Shifā'. La logique IV - Le Syllogisme (al-Qiyās). Organisme Général des Imprimeries Gouvernementales, Cairo (= Shifā': al-Qiyās)

Zimmermann FW (1981) Al-Farabi's Short Treatise and Commentary on Aristotle's De interpretatione. Oxford University Press, London 